\section{Commentary: Whether it's the best of times or the worst of times, it's the only time we've got}

\author{
Tomasz A. Timek, MD, PhD
}

The COVID-19 pandemic has upended life as we know it worldwide in 2020 and has especially challenged health care systems in affected countries. Our specialty of cardiothoracic surgery has not been spared from the wave of ill patients overwhelming hospital wards and intensive care units. However, limited access to treatment of cardiothoracic patients may have dire consequences owing to the potentially high morbidity and mortality of untreated cardiac or pulmonary pathology. The cardiac surgical community has responded with a well-coordinated response defining the early triage procedures in centers most affected in the early stages of the pandemic ${ }^{1}$ and rapid reporting of the North American ${ }^{2}$ and international ${ }^{3}$ experience for guidance. Our European colleagues have likewise "circled the wagons" to provide early descriptions of treatment algorithms from Italy ${ }^{4}$ and reporting of national data. In this issue of the Journal, Lopez-Marco and colleagues ${ }^{5}$ present a multicenter United Kingdom experience on treatment pathways and outcomes of patients with acute aortic syndromes during the first phase of the pandemic. The authors report maintained access to emergent aortic procedures and similar outcomes as in the prepandemic period. Seven patients in the series were diagnosed with COVID-19, although no deaths were attributable to the infection.

A recent study from 2 Chinese centers and the University of Michigan suggested that patients with COVID-19 infection and type A aortic dissection may be at higher risk of mortality, whereas intervention in patients recovered from recent infection may be safe. ${ }^{6}$ Two smaller Chinese reports ${ }^{7,8}$ during the first phase of the pandemic demonstrated equivalent

From the Division of Cardiothoracic Surgery, Spectrum Health, Grand Rapids, Mich. Disclosures: The author reported no conflicts of interest.

The Journal policy requires editors and reviewers to disclose conflicts of interest and to decline handling or reviewing manuscripts for which they may have a conflict of interest. The editors and reviewers of this article have no conflicts of interest.

Received for publication Dec 12, 2020; revisions received Dec 12, 2020; accepted for publication Dec 15, 2020; available ahead of print Jan 29, 2021.

Address for reprints: Tomasz A. Timek, MD, PhD, Division of Cardiothoracic Surgery, Spectrum Health, 100 Michigan Ave NE, Grand Rapids, MI 49503

(E-mail: tomasz.timek@spectrumhealth.org).

JTCVS Open 2021;5:26-7

2666-2736

Copyright $(2020$ The Authors. Published by Elsevier Inc. on behalf of The American Association for Thoracic Surgery. This is an open access article under the CC BY-NCND license (http://creativecommons.org/licenses/by-nc-nd/4.0/).

https://doi.org/10.1016/j.xjon.2020.12.007

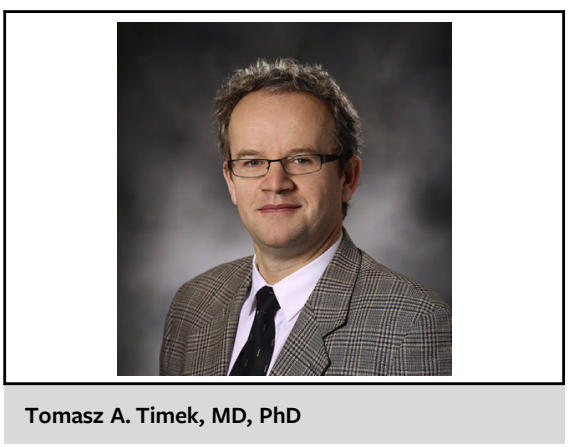

CENTRAL MESSAGE

Access to emergency aortic sur-

gical procedures during the

COVID-19 pandemic can be

maintained through resource

and structural reorganization.

results to pre-pandemic data, yet in one of the studies, all patients ultimately tested negative for the virus. How COVID19 status and timing of infection factors into perioperative outcomes of acute aortic syndromes remains unclear, but the lethal nature of this surgical pathology makes the decision making process less complicated, as most centers would not deny surgical intervention based on COVID-19 status. In more elective cardiac surgery cases, the treatment algorithm becomes more troublesome. Fattouch and colleagues ${ }^{9}$ reported $15 \%$ mortality in cardiac surgery patients who develop COVID-19 during their hospital course, emphasizing the higher-than-expected death rate based on preoperative clinical risk factors. On the other hand, limiting the access of cardiac surgical patients to operative intervention may have significant untoward effects. ${ }^{10}$

Lopez-Marco and colleagues provide organizational guidance for treating patients with aortic syndromes in a national health care system during the height of the pandemic, and they should be congratulated on their efforts to maintain clinical access. However, these efforts represent more administrative and organization strategies rather than clinical decision making. The risk-benefit ratio for cardiac surgical patients with less lethal pathologies remains to be clearly defined, as does the influence of the timing of infection on the timing of surgery.

\section{References}

1. George I, Salna M, Kobsa S, Deroo S, Kriegel J, Blitzer D, et al. The rapid transformation of cardiac surgery practice in the coronavirus disease 2019 (COVID19) pandemic: insights and clinical strategies from a center at the epicenter. $J$ Thorac Cardiovasc Surg. 2020;160:937-47. 
2. Ad N, Luc JGY, Nguyen TC, COVID-19 North American Cardiac Surgery Survey Working Group. Cardiac surgery in North America and coronavirus disease 2019 (COVID-19): regional variability in burden and impact. J Thorac Cardiovasc Surg. July 2, 2020 [Epub ahead of print].

3. Gaudino M, Chikwe J, Hameed I, Robinson NB, Fremes SE, Ruel M. Response of cardiac surgery units to COVID-19: an internationally based quantitative survey. Circulation. 2020;142:300-2.

4. Bonalumi G, di Mauro M, Garatti A, Barili F, Gerosa G, Parolari A, Italian Society for Cardiac Surgery Task Force on COVID-19 Pandemic. The COVID-19 outbreak and its impact on hospitals in Italy: the model of cardiac surgery. Eur J Cardiothorac Surg. 2020;57:1025-8.

5. Lopez-Marco A, Rosser B, Harky A, Verdichizzo D, McPherson I, Hope E, et al. The fate of patients with acute aortic syndrome during the coronavirus (COVID-19) pandemic: a UK multicenter study. J Thorac Cardiovasc Surg Open. 2021;5:17-25.

6. Fukuhara S, Tang H, Kim KM, Tan L, Shen K, Song G, et al. Type A aortic dissection during the COVID-19 pandemic: report from tertiary aortic centers in the United States and China. Semin Thorac Cardiovasc Surg. November 7, 2020 [Epub ahead of print].

7. Hu X, Wang Y, Liu J, Qiu X, Liu X, Jiang X, et al. Early outcomes of Stanford type A aortic dissection under the coronavirus disease 2019 (COVID-19) pandemic: a multicentre study from Hubei province. Interact Cardiovasc Thorac Surg. 2020;31:834-40.

8. Zhang $\mathrm{CH}$, Ma WG, Zhong YL, Ge YP, Li CN, Qiao ZY, et al. Management of acute type A aortic dissection during COVID-19 outbreak: the Anzhen experience. J Card Surg. September 16, 2020 [Epub ahead of print].

9. Fattouch K, Corrao S, Augugliaro E, Minacapelli A, Nogara A, Zambelli G, et al. Cardiac surgery outcomes in patients with coronavirus disease 2019 (COVID-19): a case-series report. J Thorac Cardiovasc Surg. October 22, 2020 [Epub ahead of print].

10. Vervoort D, Luc JGY, Percy E, Hirji S, Lee R. Assessing the collateral damage of the novel coronavirus: a call to action for the post-COVID-19 Era. Ann Thorac Surg. 2020;110:757-60. 